\title{
EDITORIAL
}

\section{Microorganismos como una alternativa al uso de agroquímicos}

\author{
Microorganisms as an alternative to the use of agricultural chemicals
}

Dr. Patricio Alberto Muñoz Torres Biotecnólogo Fundación UC Davis - Chile Life Sciences Innovation Center

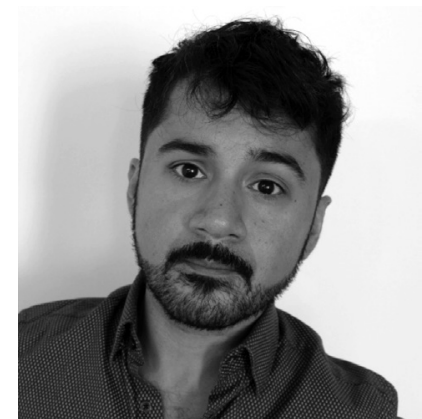

PhD Patricio Alberto Muñoz Torres Biotechnologist UC Davis - Chile Life Sciences Innovation Center.
La región de Arica y Parinacota posee condiciones ambientales particulares que permiten el cultivo de hortalizas durante todo el año, abasteciendo los mercados de la zona central durante la estación invernal. Entre sus productos agrícolas destacan el tomate y el maíz dulce, cultivos de papa, olivos y pimentón. Estas condiciones no solo son favorables para los cultivos, sino, además, para el desarrollo de plagas y enfermedades que afectan la producción. Frente a esta situación, los agricultores se ven obligados a emplear cantidades de pesticidas que superan los límites permitidos, traduciéndose en la producción de alimentos que acumulan pesticidas tóxicos para la salud y el ambiente. Además, que podrían ser como consecuencia de su uso intensivo, han emergido plagas resistentes a estos agroquímicos.

Ante este problema que requiere una pronta solución, los bioproductos representan la alternativa. Estos son productos biológicos, generalmente, derivados de microorganismos, que se presentan al usuario final en una amplia gama de formulaciones, y pueden ser clasificados funcionalmente en biocontroladores (control de plagas y enfermedades), bioestimulantes (favorecen el crecimiento) y biofertilizantes (favorecen la captura de nutrientes).
The Arica and Parinacota Region has particular environmental conditions that allow cultivation of vegetables during the entire year; it supplies the markets of the central area of Chile during winter. Important agricultural products include tomatoes, sweet corn, potatoes, olives and peppers, among others. As well as being good for agriculture, the conditions are also favorable for plagues and diseases that affect production. Farmers have been obliged to use quantities of pesticides greater than the permitted limits, producing foods that accumulate pesticides that are toxic for human health and the environment. Also, pests resistant to these chemicals have emerged as a consequence of their intensive use.

This situation requires a rapid solution, and bioproducts may be the alternative. These are biological products, usually derived from microorganisms, available in a variety of formulations, which may be classified functionally as: biocontrollers (that control plagues and diseases); biostimulants (that favor growth) and biofertilizers (that favor nutrient capture). These bioproducts are biodegradable and have little or no toxicity for humans and for the ecosystem, allowing innocuous production of vegetables. 
Estos bioproductos son biodegradables y poseen una baja o nula toxicidad para las personas y el ecosistema, permitiendo una producción inocua de hortalizas.

Naturalmente, estos microorganismos (hongos y bacterias) son capaces de colonizar las diversas estructuras vegetales, tanto en su superficie (epífitos), como en su interior (endófitos), generando comunidades ecológicas que influyen en el crecimiento, desarrollo y productividad de una planta. Poseen diversas capacidades que permitirían mitigar situaciones de estrés biótico y abiótico a través de una modulación local y sistémica de la planta, lo cual logran mediante la producción de sustancias que promueven el crecimiento de raíces, facilitando la captación de nutrientes, y otras moléculas que ayudan a su asimilación, lo cual mejoraría su productividad; estimulan la inmunidad a través de la activación de la resistencia sistémica inducida (RSI), mejorando su respuesta frente a distintos tipos de estrés; y combaten plagas y enfermedades mediante la competencia con patógenos, la producción de sustancias antagónicas y activación de RSI. Esto representa la oportunidad de utilizar estos microorganismos benéficos en la agricultura y de desarrollar diversos bioproductos.

Sin embargo, en la región de Arica y Parinacota existen áreas cultivables con altas concentraciones salino-bóricas, con un proceso de salinización creciente, lo cual limita el uso de los bioproductos comerciales disponibles. En general, los bioproductos poseen una alta efectividad en ambientes similares al lugar del que fueron obtenidos, y pierden sus propiedades al ser empleados en condiciones disímiles, como ocurre en esta región. Por lo tanto, es vital desarrollar una solución que incluya formulaciones de bioproductos que actúen óptimamente bajo las condiciones que impone este sector productivo.

La Universidad de California Davis Chile y la Universidad de Tarapacá han aprovechado la oportunidad de estudiar las comunidades microbianas asociadas a diversos cultivos, las cuales están naturalmente adaptadas a las condiciones
The fungi and bacteria that produce these products are naturally capable of colonizing different plant structures, both on their surfaces (epiphytes) and inside them (endophytes), generating ecological communities that affect the growth, development and productivity of a plant. These microorganisms have a number of capabilities that mitigate situations of biotic and abiotic stress through local and systematic modulation of the plant, by the production of substances that promote root growth, facilitating nutrient capture, and other molecules that aid in their assimilation, which improves their productivity. They also stimulate immunity by activating induced systemic resistance (ISR), improving the response to different types of stress, and they fight diseases and plagues by competing with the pathogens, producing antagonic substances and activating ISR. These beneficial microorganisms may thus be used in agriculture and may be the source of various bioproducts.

However, in the Arica and Parinacota region there are cultivatable areas with high and increasing concentrations of boron and salts, which limits the use of the commercially available bioproducts. Bioproducts usually have high efficacy in environments similar to those where they were obtained, and generally lose their properties if they are used in conditions different from those in their original sites, as occurs in this region. Thus it is vital to develop a solution that includes formulations of bioproducts that act optimally under the conditions that this productive sector impose.

The University of California at Davis and the Universidad de Tarapaca have responded to this challenge to study the microbial communities associated with a number of crops that are naturally adapted to the environmental conditions of this region. Identifying these microorganisms offers the opportunity to develop new bioproducts for agriculture that function optimally in zones where the environmental conditions limit the production of crops. These institutions will be searching for solutions that incorporate microorganisms native to arid environments, allowing the development of 
ambientales de la región. Lograr la identificación de estos microorganismos ofrece la oportunidad de desarrollar nuevos bioproductos de uso agrícola, que funcionen óptimamente en zonas donde las condiciones ambientales limitan la producción de los cultivos. Se ha destacado la necesidad de generar una solución que incorpore microorganismos nativos de ambientes áridos, de modo que permitan desarrollar bioproductos eficientes y efectivos bajo las condiciones que impone esta zona del país, propiciando una producción inocua de alimentos, reduciéndose el uso de agroquímicos tóxicos y favoreciéndose la producción, y combatiendo plagas y enfermedades mediante alternativas que son compatibles con la salud y amigables con el ambiente. efficient and effective bioproducts in the conditions imposed by this area of the country, allowing innocuous production of foods, reducing the use of toxic agrochemicals, favoring production and combating plagues and diseases using alternatives that are compatible with health and environmentally friendly. 